\title{
The Calcutta School of Tropical Medicine: Institutionalizing medical Research in the Periphery
}

\author{
HELEN POWER*
}

The creation of the Calcutta School of Tropical Medicine (CSTM) reveals much about the priorities of colonial medicine in India during the early years of this century. Efforts to found a school of tropical medicine in the periphery of empire involved complex negotiations between local, central Indian, and imperial government agencies as well as municipal politics over a ten year period from 1910-1920. The involvement of some sections of the Indian middle class in Calcutta supports David Arnold's view that "in the years after 1914 [India's emerging elites] were to take up Western Medicine as part of their own hegemonic project". ${ }^{1}$ A growing number of western-educated Indian medical practitioners were calling for the civil branch of the Indian Medical Service (IMS) to loosen its stranglehold on government medical posts, while the IMS was itself under threat because of falling white recruitment. This paper discusses the foundation of the CSTM from the perspectives of these various groups, placing the organization of medical education and research in tropical diseases in a wider social and political context. Mark Harrison has analysed the implementation of public health policies and the aim is to augment such work by focusing on the foundation of the CSTM, as a detailed example of such action. ${ }^{2}$

The early history of the school has been divided into three overlapping phases: planning; the organization of an endowment fund; and the arrangement of the school's professorial staff. Each of these stages demonstrates the problems of institutionalizing tropical medicine for postgraduate education and research in India. This paper is therefore part of a growing interest in the organization of research and teaching in the periphery, which can be contrasted with schools of tropical medicine in Britain and elsewhere during the same period.

The central character in the foundation of the school was Sir Leonard Rogers (1868-1962) of the Indian Medical Service, professor of pathology at the Calcutta Medical College. ${ }^{3}$ Rogers represented the general interests of the IMS, in particular the officers of the civil branch and their difficulties in conducting medical research in India.

\footnotetext{
* Helen Power, PhD, Department of Economic and Social History, University of Liverpool, 11 Abercromby Square, Liverpool L69 3BX.

I would like to thank Bill Bynum for his continuous support and confidence, the four anonymous referees of Medical History, and the Wellcome Trust for generously funding the research for this paper.

${ }^{1}$ David Amold, Colonizing the body: state medicine and epidemic disease in nineteenth-century India, Berkeley, University of California Press, 1993, p. 294.
}

\footnotetext{
${ }^{2}$ Mark Harrison, Public health in British India: Anglo-Indian preventive medicine 1859-1914, Cambridge University Press, 1994.

${ }^{3}$ For details on the work and career of Rogers see Helen Power, 'Major-General Sir Leonard Rogers FRS (1868-1962): tropical medicine in the Indian Medical Service', PhD thesis, University of London, 1993; and his autobiography, Leonard Rogers, Happy toil: fifty-five years of tropical medicine, London, Frederick Muller, 1950.
} 


\section{Helen Power}

The school initially embodied his research priorities and methodology though ironically he had retired and returned to England before it opened in 1921. By that time other individuals and agencies were reshaping the school to serve different interests which were perhaps more suited to the health needs of Indians than to the benefit of the IMS.

\section{Schools of Tropical Medicine: an Established Trend}

It is not hard to see why proposals emerged to found a school of tropical medicine in Calcutta. By 1910, when planning for the school began, such institutions were found across the globe and these offered a number of possible models for emulation. Such schools, which largely concentrated on postgraduate study and research, were part of a wider institutionalization of medical research that began in the latter part of the nineteenth century and gained pace after 1900. Research in tropical medicine, as exemplified by the investigation of parasites and vectors, was well suited to the increasing role of the laboratory in medical practice, teaching and research. ${ }^{4}$ Tropical medicine underwent more than an increase in tempo after this date; its aims and ideology were transformed along with the implementation of a new concept of the empire. The stimulus to realize the economic potential of the tropical empire through "constructive imperialism" was championed by Joseph Chamberlain, Secretary of State for the Colonies from 1895-1903..$^{5}$ Although his policies were aimed particularly at Africa and the West Indies, India too was affected by an enthusiasm to make the tropical colonies pay their way and more. As Michael Worboys has argued, "constructive imperialism" saw the tropics ripe for development by scientific means for the benefit of the metropolis. ${ }^{6}$ Medicine, particularly laboratory based scientific medicine, was to play a supporting role in achieving this goal. In India the CSTM offered a different potential to the groups who supported it, especially members of the Indian community. Aparna Basu has looked at the institutionalization of science from the Indian perspective, describing how Indian initiatives increased from the last quarter of the nineteenth century partly in an effort to combat racial discrimination. ${ }^{7}$ The establishment of the CSTM shows similar patterns at work in medicine.

By 1910 the London and Liverpool schools had already celebrated their first ten years of service. The Tropical Diseases Research Fund was established in 1904 by the Colonial Office, and in 1908 the joint Royal Society/Colonial Office Sleeping Sickness Bureau was inaugurated, and later expanded into the Tropical Diseases Bureau at the Imperial Institute. ${ }^{8}$ The American Public Health Laboratory in Manila had been founded in $1902,{ }^{9}$

\footnotetext{
${ }^{4}$ William F Bynum, Science and the practice of medicine in the nineteenth century, Cambridge University Press, 1994, pp. 92-117.

$5 \mathrm{~J}$ L Garvin and Julian Amery, The life of Joseph Chamberlain, London, Macmillan, 1951; Robert V Kubicek, The administration of imperialism: Joseph Chamberlain at the Colonial Office, Durham, Duke University Press, 1969.

${ }^{6}$ Michael Worboys, 'Science and British colonial imperialism, 1895-1940', DPhil thesis, University of Sussex, 1979.

${ }^{7}$ Aparna Basu, 'The Indian response to scientific and technical education in the colonial era,
}

1820-1920', in D Kumar (ed.), Science and empire: essays in Indian context 1700-1947, Delhi, Anamika Prakashan, 1991, pp. 126-38; Deepak Kumar, 'Racial discrimination and science in nineteenth-century India', Indian econ. soc. Hist. Rev., 1982, 19: 63-82.

${ }^{8}$ Michael Worboys, 'The Imperial Institute: the state and the development of the natural resources of the colonial empire, 1887-1923', in J MacKenzie (ed.), Imperialism and the natural world, Manchester University Press, 1990.

${ }^{9}$ Teodora V Tiglao and Wilfred L Cruz, Seven decades of public health in the Philippines (1898-1972), Tokyo, Seamic, 1975. 
and the European powers had also institutionalized research in tropical medicine. ${ }^{10}$ The Institut für Schiffs- und Tropenkrankheiten in Hamburg was founded in 1900, the Belgium State School of Tropical Medicine in Brussels in 1906, and lectures on tropical diseases were given in the Paris Faculty of Medicine. Under the French Minister of War, a special school for the sanitary service of colonial troops provided courses in bacteriology, parasitology, military and colonial hygiene, prophylaxis in tropical diseases and sanitary policing. The Institute of Medical Research at Kuala Lumpur opened in 1900, in association with the London school, and in Africa the Wellcome Tropical Laboratory was established at the Gordon Memorial College in Khartoum. ${ }^{11}$ The School of Medicine in Cairo, connected with the Kasr-el-Ainy Hospital, conducted research for the Sanitary Maritime and Quarantine Council of Egypt. There was also the Pasteur Institute in Tunis producing sera and vaccines as well as acting as a research laboratory. ${ }^{12}$

In India the plague epidemic which began in Bombay in 1896 stimulated the formal organization of disease control. ${ }^{13}$ In 1899 Surgeon-General Robert Harvey, Sanitary Commissioner with the Government of India (GoI), proposed the building of a central research laboratory and a local laboratory in each province, although there was considerable delay in implementing this scheme. In the meantime W M Haffkine's manufacture of plague vaccine required accommodation on a large scale, and the Old Government House, Parel, Bombay, was used as a laboratory of sorts. ${ }^{14}$

In 1900 a long-proposed Pasteur Institute was opened in the hill station of Kasauli, followed by the King's Institute of Preventive Medicine at Guindy in the Madras Presidency. In 1906, when official sanction was granted, Kasauli became the site for the Central Research Institute. ${ }^{15}$ The primary function of many of these laboratories was vaccine production. Initially these institutions were staffed by researchers on short-term postings, but in 1905 the position was regularized by the formation of a separate cadre of IMS officers: the Bacteriological Department of the GoI. All the laboratories provided some opportunity for research, but there was no access to patients. Only in the medical colleges were there facilities for investigating tropical diseases by linking the clinic and the pathological laboratory. However, the staff were employed to teach undergraduates: research depended on an individual's initiative and energy.

In 1910 the interests of medical research, especially on the clinical side, received a boost with the appointment of Charles Pardey Lukis (1857-1917) as Director General of the IMS (DGIMS). ${ }^{16}$ Before his promotion, Lukis had been Principal of the Calcutta

\footnotetext{
${ }^{10}$ Michael Worboys, 'Tropical diseases', in W F Bynum and R Porter (eds), Companion encyclopedia of the history of medicine, vol. 1, London, Routledge, 1993.

${ }^{11}$ Hairudin Bin Harun, 'Medicine and imperialism: a study of the British colonial medical establishment, health policy and medical research in the Malay Peninsula, 1786-1918', PhD thesis, University of London, 1988.

12 Nancy E Gallagher, Medicine and power in Tunisia 1780-1900, Cambridge University Press, 1983.

${ }^{13}$ Harrison, op. cit., note 2 above, pp. 141-58; Ian $\mathrm{J}$ Catanach, 'Plague and the tensions of empire: India
}

1896-1918', in D Arnold (ed.), Imperial medicine and indigenous societies, Manchester University Press, 1988.

14 Ilana Löwy, 'From guinea pigs to man: the development of Haffkine's anticholera vaccine', $J$. Hist. Med. allied Sci., 1992, 47: 270-309.

15 India Office Records, hereafter IOR, V/26/840/12, Health Survey and Development Committee: 1943-45.

${ }^{16}$ For obituaries see, Indian J. med. Res., 1917-18, 5: 273-76; 'Charles Pardey Lukis', Plarr's Lives of Fellows of the Royal College of Surgeons of England, revised by Sir D'Arcy Power, 1920, pp. 741-2. 


\section{Helen Power}

Medical College and the professor of materia medica. He was well aware of the difficulties in combining research and administration. By the date of his appointment, many early members of the bacteriological cadre were working in administrative positions. He wanted to assemble a further set of suitably-trained men, arguing that experts should be immediately available during crises, and that it was impractical to wait up to two years for sanction from the Secretary of State in London. With Sir Harcourt Butler's help, he set up the Indian Research Fund Association (IRFA), directly responsible to and funded by the GoI, and administered by a scientific advisory board. ${ }^{17}$ This was similar to the Medical Research Council, which was formed in Britain two years after Lukis and Butler's success in India, and shows that India was not dilatory in all matters of medical organization.

In addition to such government initiatives, private investment in medical research was also fostered. A Medical Section of the Asiatic Society of Bengal started in 1906, providing a discussion forum. ${ }^{18}$ The Indian Science Congress, equivalent to the British Association for the Advancement of Science, held its first meeting in Calcutta in 1914. ${ }^{19}$ These were generally European dominated schemes, but Indian initiatives were not lacking. In 1898 the industrialist Jamestji N Tata had proposed to the Viceroy, Lord Curzon, that he would give three million rupees for buildings, equipment and an endowment fund to found a technical college. The Viceroy stalled and it was not until 1909, when Tata was dead and Curzon back home in England, that the plan was resurrected by the Maharajah of Mysore's gift of money and land in Bangalore. The GoI also contributed a lump sum and a recurrent budget. The Indian Institute of Technology, the first postgraduate scientific research institution in India, opened in $1911 .^{20}$

On a smaller, local scale the Calcutta Medical Club was formed in 1906. Just as the Medical Section of the Asiatic Society afforded a venue to present lectures, or interesting cases, the Medical Club served the western-educated indigenous practitioners. In 1908, the Clinical Research Association was started in a small room belonging to the Club. It was described as the first attempt by non-official medical men in eastern India to conduct laboratory work outside Government institutions. ${ }^{21}$ The founding of the CSTM was therefore part of a general movement early this century to organize the study of tropical medicine. However, the significance of the school was heightened by the situation in Calcutta where a large number of qualified medical men were not part of the IMS, an aspirant middle class was pushing for political control, and Leonard Rogers of the IMS was determined to improve the conditions of service for existing and future members.

\footnotetext{
${ }^{17}$ C G Pandit and K Someswara Rao, Indian Research Fund Association and Indian Council of Medical Research, 1911-1961: fifty years of progress, New Delhi, Cambridge Printing Works, 1961.

18 'Annual report for 1906', J. Asiatic Society of Bengal, 1907, 3: 16.

${ }^{19}$ Sir A Mukhopadhyaya, 'Presidential address: first Indian science congress’, ibid., 1914, 10: 12.
}

\author{
${ }^{20}$ Daniel $\mathbf{R}$ Headrick, The tentacles of progress: \\ technology transfer in the age of imperialism, \\ 1850-1940, New York, Oxford University Press, \\ 1988. \\ ${ }^{21}$ N Mukherjee, Guide book to Calcutta, Calcutta, \\ Indian Science Congress, 1928.
}




\section{Planning}

In early-twentieth-century Calcutta, the Medical College and Hospital were situated on College Street in the northern part of the city; the "native quarter". These institutions served as a focus for government medical education and care in the "second city of empire". ${ }^{22}$ The Medical College Compound also housed the Eden and Prince of Wales Hospitals. From 1824 the Medical College had prepared students for either the Licence in Medicine and Surgery (LMS), or the MB Degree using a syllabus derived from that of British medical schools. ${ }^{23}$ In an attempt to improve the quality of the students' education, the Indian Universities Act (1904) abolished the LMS in 1906. After this date a student was required to spend one year studying the basic natural sciences, followed by two years studying anatomy and physiology, and then to undertake three years clinical work in medicine and surgery in a recognized hospital. ${ }^{24}$ These changes to the syllabus increased the workload on the staff and stretched the facilities of the College.

In 1908 a new chair of biology replaced that of comparative anatomy and zoology, reflecting a greater emphasis on biology in the medical curriculum. However, academic initiative did not automatically mean an increase in space. The Senate of Calcutta University was worried about the teaching areas available for biology and pathology, and submitted a request to the Government of Bengal $(\mathrm{GoB})$ for new buildings and equipment. These essentially private negotiations were made public by a letter, published in the Englishman in March 1910, from Dr McCabe Dallas, working on a tea estate in Assam. Dallas suggested the establishment of a research institute for the investigation of tropical diseases, especially those afflicting the coolie labour force. A series of letters and a leading article were subsequently published in support of this proposal. The leader stressed Calcutta's potential for such an institute in combination with the need to expand the facilities for medical education: the Medical College Hospital could provide the necessary clinical material, and the enhanced pathological and physiological laboratories the scientific site. The author of the leading article was Leonard Rogers, who as professor of pathology at the Medical College was involved in pressing the GoB for improved teaching and research space in the biology laboratories, and he had taken the opportunity of bringing the desirability of strengthening government research facilities into the public arena. Notice of the suggestion was also published in the British Medical Journal in April 1910, in a feature from the Indian Correspondent, who was none other than the ubiquitous Rogers. The publicity was designed to improve his working conditions, to further research in tropical medicine, and to provide employment for "the number of medical officers in India who have already distinguished themselves in medical research". ${ }^{25}$ Further publicity was generated following the death of King Edward VII, the King Emperor of India, on 7 May 1910. Suggestions for memorials included the usual assortment of hospitals, orphanages, and sanatoria, but the Asiatic Society of Bengal proposed the establishment of a school of tropical medicine. As a memorial this was a short-lived idea, the GoB settling for a statue of the late King, but the attention was useful nevertheless.

22 P C Bagchi, The second city of empire, Calcutta, U Ray \& Sons Press, 1938.

${ }^{23}$ Poonam Bala, Imperialism and medicine in Bengal: a socio-historical perspective, New Delhi, Sage Publications, 1991.

\footnotetext{
${ }^{24}$ Calcutta Medical College, Centenary of the medical college of Bengal, Calcutta University Press, 1934.

${ }^{25}$ Quoted in Leonard Rogers, 'Proposed school of tropical medicine in Calcutta', Br. med. J., 1910, i: 1010.
} 


\section{Helen Power}

Away from the public view, Lukis took up the matter of the biology laboratories and the idea of a school of tropical medicine with the central government in India. In a personal letter to Rogers he indicated that "the GoI has practically accepted certain proposals which I [Lukis] have made to them in this commission and they will shortly be forwarded for the opinion of Local Government". ${ }^{26}$ Rogers also contacted Branfoot, President of the Medical Board of the India Office in London, for support.

In response to Lukis, the GoI Home Department wrote to the GoB in July 1910 with their proposals for a school of tropical medicine in Calcutta. The GoI were sure that such a school:

the establishment of which could hardly fail to stimulate scientific research, would be most useful. It is anomalous that medical men resident in India should have to go for the scientific study of tropical diseases common in this country, to such places as Liverpool and Greenwich, where the material must necessarily be scanty. Also, there must be a large number of men trained in the medical schools of this country anxious to undergo a course of training in tropical medicine and capable of profiting by it, but unable to afford to go through a postgraduate course in England. It seems desirable therefore that special facilities for the study of tropical disease should be provided in India for both official and non-official medical men. ${ }^{27}$

The GoI set out in a general plan the features they wanted incorporated in the school; requirements that were in effect the suggestions Lukis had put to them:

The GoI think it obviously desirable that any special teaching of this sort should be associated with an existing medical college and a large and well-equipped hospital and that it would be a great advantage to have the school of tropical medicine organised as part of the Calcutta Medical College. Teaching staff of the college already includes ... several officers well qualified to give courses of instruction in tropical medicine, and the laboratories and hospitals attached to or connected with it would afford ample opportunities for clinical study and research. The GoI, while they hope in time to be able to establish a fully equipped school of tropical medicine in Calcutta with a special staff of its own, think it necessary, in existing financial conditions, that a beginning should be made on a small and unpretentious scale. ${ }^{28}$

The GoI intended to use the new teaching laboratories in the Medical College provided by the GoB and the existing teaching staff, who would receive an additional salary allowance and have the assistance of two demonstrators. The GoI suggested that the Senate of Calcutta University should be approached about administering examinations and the award of Diplomas, then closed the letter with their own contribution:

If the proposed school is established, for the present on the modest scale suggested [and] the courses would be open to medical men throughout India and in particular to all officers of the IMS, the GoI would be willing to meet the direct expenditure from Imperial revenues. ${ }^{29}$

Several things are apparent from this letter. The GoI was prepared at this stage to take an initiative in educating its medical officers, and proposed to extend this to non-official medical men. This dealt with two matters simultaneously. First, the GoI hoped to raise

\footnotetext{
${ }^{26}$ Contemporary Medical Archives Centre, $\quad{ }^{28}$ Ibid. Wellcome Institute, hereafter CMAC,

${ }^{28}$ Ibid.
${ }^{29}$ Ibid. PP/ROG/C.18/12, Lukis to Rogers, 22/06/1910.

${ }^{27}$ IOR, P/8442, Proc. No. 89, letter no. 834 , $20 / 07 / 1910$.
} 


\section{The Calcutta School of Tropical Medicine}

standards among its officers. Second, by making the school open to all, they appeared to be fostering the development of an independent, indigenous, western-educated medical profession. The GoB claimed that such an independent profession already existed, albeit outside the ranks of government service, ranging from the village midwife, traditional healers such as the kabiraj and hakim, homoeopaths, graduates of Indian medical schools, to fully qualified graduates of government medical colleges and European universities. None the less, the GoB considered "the encouragement of the Western school of allopathic medicine, which is what is really intended, is dependent mainly upon the gradual conversion of the people to an appreciation of the advantages of this system" ${ }^{30}$ Although "at the present moment it is impossible to contemplate any extensive transfer to private practitioners of appointments now held by officers of the IMS", those practitioners seeking employment with "public bodies, private associations and native states" would benefit from attending a school of tropical medicine without posing a threat to the government positions and administrative posts held by the IMS. ${ }^{31}$ This attitude reduced the effect of the Secretary of State, John Morley's decision of 1905 to accelerate the process of "Indianization", replacing white officers with Indians, by limiting the number of places for the British. In reality the Gol's apparent enthusiasm for the project was tempered by their emphasis on a "small and unpretentious scale", which was reflected in the limited amount of money made available. Its worth in real terms was aptly demonstrated by the idea of sharing staff with the Medical College. In no way could this scheme be satisfactorily compared with the London and Liverpool Schools of Tropical Medicine where IMS officers went to study for and obtain Diplomas in Tropical Medicine and Hygiene.

Early in 1911, the GoB replied to the Gol's request, confirming their approval and outlining two possible plans for the combined biology classroom and school. These were prepared by a committee made up of Cowley, Superintendent Engineer of the Bengal Public Works Department; Rogers, Professor of Pathology; R A Lloyd, Professor of Biology; and J T Calvert, Principal of the Medical College. It was at first suggested that thirty cottahs of land to the north-east of the Medical College should be purchased for a building with foundations strong enough to carry a second floor, which would initially have a biology classroom on the ground floor and the school on the first. A second suggestion was to acquire the whole area of land south of Colootallah Street, on which a more generous building could be constructed allowing for expansion outwards as well as upwards. Given the high cost of land, rising rapidly because of the Calcutta Improvement Trust (CIT), ${ }^{32}$ and on the advice of Lt-Col. George F A Harris, Inspector General of Civil

\footnotetext{
${ }^{30}$ IOR, P/8443, H. Wheeler, Sec. GoB to Sec. GoI, Home dept, 30/09/1909.

${ }^{31}$ Ibid.

32 In 1911 the Calcutta Improvement Act was passed and the Calcutta Improvement Trust created. The preamble of Act $\mathrm{V}$ of 1911 explained the need for the legislation: "It is expedient to make provision for the improvement and expansion of Calcutta by opening up congested areas, laying out or altering streets, providing open spaces for purposes of
}

ventilation or recreation, demolishing or constructing
buildings, acquiring land for the said purposes and
for the rehousing of persons of the poorer and
working classes displaced by the execution of
improvement schemes." These activities greatly
increased already inflated real estate prices, IOR,
V $24 / 2918$, Annual report of the Calcutta
Improvement Trust for the period ending 31 st March-
1912, p. 7 . 


\section{Helen Power}

Hospitals, Bengal (IGCH), the GoB decided to buy the larger plot of land. ${ }^{33}$ The biology classroom could now be built large enough and with sufficient north light for microscopy, and could take all the undergraduates in a single session, instead of in several smaller groups. This would fulfil the requirements for teaching biology and ensure that there was sufficient time left for the postgraduates. The Senate of the Calcutta University endorsed the scheme and agreed to grant a diploma at the end of a suitable course. ${ }^{34}$

The following June (1912) the GoI submitted a detailed proposal to the Secretary of State in London for sanction. ${ }^{35}$ The money, which had not been available in the 1911 budget, was to come from the opium surplus. The Secretary of State's reply summarized the stage the project had reached:

your [GoI] present proposals are as follows (1) to build a tropical school at a cost of Rs 5,29,873 and a biological laboratory at a cost of Rs 1,66,821 (2) to assign certain additional teaching duties to the principal and to the professors of pathology and biology and to give to each of these three officers an additional allowance of Rs $200 /$ month and (3) if necessary to employ two demonstrators on salaries of Rs 150/month. ${ }^{36}$

Early in 1913, through the IGCH, Rogers submitted plans for enlarging the proposed school. The plans sanctioned by all three governments had been based on the smaller plot of land than the one actually purchased. Harris was prepared to support Rogers by forwarding his letter to the GoB's Medical Department, but was cautious about "making fresh proposals on a matter which may not unnaturally have been regarded as settled". ${ }^{37}$ Rogers was keen to maximize the use of the larger plot of land. In a long letter he used as justification a line from the Gol's letter 834, dated 20 July 1910, describing the intention to "establish a fully equipped School of Tropical Medicine in Calcutta" ${ }^{38} \mathrm{He}$ was to use this letter again in the future whenever he wanted to enhance the school, often outside its original context.

Rogers considered that the shared biology classroom on the ground floor was now likely to prove inadequate with the increasing number of students admitted for the preliminary scientific examination of the MB degree (176 in February 1913). The undergraduates would have to be divided into at least two groups for teaching and this would leave insufficient time for the postgraduates. An additional classroom could be built on the first floor, but at the expense of one of the two large research rooms. At a meeting between Harris and the school committee, it was pointed out that now that the larger plot of land had been purchased, the entrance could be situated on the wider Colootallah Street. The lecture theatre could be moved back from the road to a quieter location and "a very much more convenient and imposing building constructed". ${ }^{39}$ Just redesigning the first floor classroom required new plans, and Rogers thought it opportune to redraw the entire building. Perhaps anticipating difficulties, he wrote privately to Lukis,

\footnotetext{
${ }^{33}$ West Bengal State Archives, hereafter WBSA, Proc. No. 17, Municipal Dept, file 2s/13-3, no. 683 medl Calcutta, 06/03/1911.

34 WBSA, Proc. No. 14 , file $2 \mathrm{~s} / 13$, no. 3490 , Calcutta, 21/02/1911, G Thibaut, Registrar Calcutta University to Sec. GoB Municipal (medical) Dept.

35 WBSA, Procs Nos 24-33, Municipal Dept, file $2 S / 15,29 / 06 / 1911$.
}

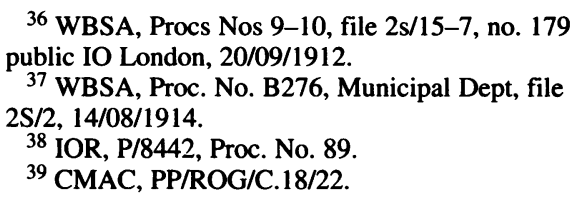




\section{The Calcutta School of Tropical Medicine}

informing him of the developments, asking for his support, and "an extra lakh [Rs 100,000 ] if necessary out of the one and a half cores to be allotted to sanitation in the prosperity budget just announced". ${ }^{40}$ Rogers considered it "essential that the whole of the second floor space should be made available if we are not to be utterly inferior to the London School of Tropical Medicine". ${ }^{41}$ There were several reasons for Rogers' repeated emphasis on a favourable comparison with the two schools of tropical medicine in Britain. First, potential students would want to attend a school in India which offered a course of study and a qualification comparable with those obtainable at home. Second, the prestige of the IMS and hence its ability to attract quality English recruits had fallen. Rogers considered the facilities of the CSTM could help to restore the service's reputation. Third, doctors who practised overseas had traditionally been viewed as inferior upon their return home. The potential for producing high quality research would be enhanced in such surroundings and this was what the CSTM should aim to offer the IMS. ${ }^{42}$

In March 1913 new plans had been drawn up, and again two alternative schemes were proposed. The first, a three-storied building, was to be on very similar lines to the twostoried one already agreed to. This involved an overspend of Rs 80,000 , some of which could be off-set by forgoing the temperate room. The second and more ambitious plan was to enlarge the existing floor space and provide all the necessary accommodation on two floors, but with foundations to carry a third when expansion was needed, allowing for "such an important addition as a Pharmacological Institute for investigating the many Indian drugs or any other line of medical research being easily provided for at any further stage without having to take up more land". 43 This would cost an additional lakh of rupees, but he admitted that if money could be found it was the best plan.

Lukis agreed to provide the extra lakh via a non-recurring grant from the IRFA, which thus fulfilled one of the reasons for its creation, instead of waiting up to two years for sanction to come through the usual channels, the governors of the fund responded to a request and dealt with it when the need was most acute. The site was cleared and building scheduled for later in 1913.

So far mediation between the local, central and imperial governments over the creation of the CSTM had been relatively easy, indicating a degree of consensus over the value of such a school to imperial India. The governments of India and Bengal, and the Secretary of State in England were prepared to acknowledge the importance of formal research and better education in tropical medicine. The consensus and recognition of the value of establishing laboratory medicine did not extend to the municipal level, as the dispute with the Calcutta Improvement Trust (CIT) indicates.

\section{The Calcutta Improvement Trust}

The principal duty of the CIT was the construction of new main roads in Calcutta, aiding the movement of traffic to the suburbs and promoting expansion beyond the congested inner city areas. Behind such schemes was the removal of the overcrowded

\footnotetext{
${ }^{40}$ CMAC, PP/ROG/C. $18 / 25$.

${ }^{41}$ CMAC, PP/ROG/C. $18 / 24$.

42 See Harrison, op. cit., note 2 above, pp. 6-35, and R Jeffrey, The politics of health in India,
}

Berkeley, University of California Press, 1988, for a discussion on the general status of the IMS.

${ }^{43}$ CMAC, PP/ROG/C.18/26. 


\section{Helen Power}

bustees [slums], with their Indian, disease-harbouring inhabitants, from the neighbourhood of the European residents. ${ }^{44}$ Only two north-south roads traversed northern Calcutta between the River Hooghly and Upper Circular Road. As part of the Trust's fourth scheme, Halliday Road, which ran parallel to College Street, was to be substantially widened to form a major route from the centre to the north of the city. The necessary land was to be found from the school's site. Not only would the entire area be reduced by one third, but the valuable north facing aspect of the biology classroom, essential for microscopy and dissection, would be lost.

On the evening of 22 September 1913 Rogers found a hastily written note from the architect: "Have you heard that the Improvement Trust want a slice off the West End of Tropical School of Medicine which as far as I can gather will upset things dreadfully". ${ }^{45}$ Rogers met the valuer of the Trust the next day, 23 September, and they agreed that the school committee would surrender seventy-five of the ninety-five feet requested. In return they would gain additional land at the back of the existing site, and an undertaking from the Trust to maintain the building line and construct a road to the new entrance. Two days later the valuer was persuaded by the Chairman of the CIT to go back on his word and he again demanded the full ninety-five feet from the school's land. On the other side of Halliday Road, large Indian-owned houses would cost much more to buy and demolish than the land already cleared at the cost of the Bengal and Indian Governments.

In the ensuing battle between those members of the GoB in favour of the school (Major General Edwards IMS, head of the Bengal Medical Department and William Duke, ICS Minister in charge), and those apparently concerned with the civic improvement of Calcutta, it was clear that a road widening scheme would take precedence over an all-India research institute for tropical medicine.

Rogers travelled up to Darjeeling to try to obtain a favourable outcome to this latest crisis. Yet another set of plans were prepared, and in what was to become the completed building there were now three stories with foundations designed to take a fourth. In addition to the increase in size, the L-shaped building would have its entrance on the new Central Avenue. The pro-school lobby won the day, thanks to the support of Edwards and Duke. Not only were the CIT forced to back down, but the plans for the school had been considerably improved. The rhetoric behind the Calcutta Improvement Act, like that surrounding the proposed school, spoke of benefiting all. However, the Trust's record on rehousing was lamentable, and cleared land was often sold at a profit to private landlords. The new rents were beyond the means of the evicted poor who were forced to move to the outskirts of town, and whose lives and sense of community were disrupted accordingly. ${ }^{46}$

\section{The Calcutta School of Tropical Medicine Endowment Fund}

On 24 February 1914, the foundation stone of the CSTM was laid by Lord Carmichael, the Governor of Bengal. This ceremony served as a minor imperial spectacle, and launched the Calcutta School of Tropical Medicine Endowment Fund. The fund was set

\footnotetext{
${ }^{44}$ Harrison, op. cit., note 2 above, pp. 184-5, describes a similar objective for Bombay, although this was in response to the plague epidemic.

45 CMAC, PP/ROG/C.18/41.

${ }^{46}$ See the Hindoo Patriot, 02/09/1912, and also
}

23/09/1912, A Lament from Colootallah, a poem describing life in the street where the school was housed, and the forced removal of its inhabitants to the outskirts of Calcutta. 


\section{The Calcutta School of Tropical Medicine}

up to provide additional money for the salaries of research workers and to endow an attached hospital for tropical diseases, completing the first comprehensive teaching and research institute in the British colonies. Rogers' own work had combined clinical and pathological observation, with acknowledged results in differentiating fevers and reducing the mortality in amoebic hepatitis and cholera ${ }^{47} \mathrm{He}$ was aware of his anomalous position as a Professor of Pathology with no beds under his control, reliant always on the goodwill of others for access to clinical cases. Energy and dedication may have marked him out as a researcher among the ranks of the IMS, but his was not an official salaried position. It had been arranged that the Professor of Tropical Medicine should have forty beds in the Medical College Hospital. Rogers wanted more than this, for his own professional gain and for the status of the school. He considered that the great wealth of clinical material in the streets of Calcutta could be harnessed most efficiently if the CSTM had a purpose-built hospital attached. In this way, the school would be made a leading centre because of and not despite its position.

When he learned that the London School had sought and obtained funds from the Indian Railways, Rogers contacted Surgeon-General A M Crofts, mentioning that he had received offers of donations towards the school and its research work. These had been refused, since no one had the authority to accept such money. Rogers suggested that an endowment fund could be started and wrote to Lukis: "as we cannot expect to get more than four IMS men for the Calcutta School staff, we must get endowments if we are to make full use of the accommodation and facilities for research here". ${ }^{48}$ The GoB sanctioned the creation of the fund very early in 1914, allowing a list of donors to be drawn up and read at the foundation ceremony. With his usual enthusiasm Rogers informed Lukis:

I am getting in touch with Rockefeller through Professor Flexner over the hookworm work, and also hope to get substantial help from Wellcome and Park Davies, and possibly from one to two Rajahs, while Koilash has already got some substantial promises from Marwaris . . . if we can get enough money one way or another the hospital might easily be opened one year after the school. ${ }^{49}$

A report of the foundation ceremony was published in the Statesman of 25 February 1914. The event was well staged: Colonel Harris addressed the business community and called for support. Lord Carmichael appealed to the Indian and British communities by describing the successes of the Wellcome Laboratories at Khartoum. Speaking for the GoI, Lukis urged the public to believe that "the development of research into the causes of and mode of spread of tropical diseases is a matter to which the GoI attaches the greatest importance". 50

Plans for the hospital had been drawn up early in 1914, and on their honeymoon in Darjeeling in September, Rogers and his new wife (the former Sister-in-Charge at the European General Hospital, Elsie Una North) worked out the fine details. Money for the Fund came from individuals and businesses, both Indian and European. In addition Rogers

\footnotetext{
${ }^{47}$ In addition to numerous papers, there were three major textbooks, Leonard Rogers, Fevers in the tropics, London, Henry Frowde: Hodder \& Stoughton, 1908; idem, Cholera and its treatment, London, Henry Frowde, Oxford University Press, 1911, idem, Dysenteries, their differentiation and
}

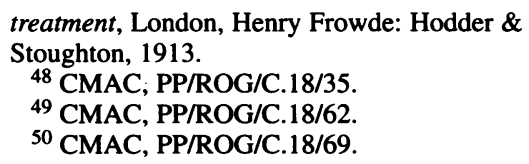




\section{Helen Power}

collected funds from the tea, jute, and mining associations on a quasi-business proposition. In return for Rs 20,000 per annum for 5 years, he suggested that diseases afflicting the labour force of these industries could be better understood and even prevented. Thus indirectly, he argued, the planters, mill and mine owners would be saved many more rupees in inefficient and lost labour. Whatever the reality, the associations were convinced by his rhetoric. Kala-azar research was paid for by the tea planters, hookworm by the jute wallahs, and dysentery by the mine owners, exemplifying the interrelationship of medicine and the economic development of the colonies, which had been Chamberlain's goal.

From the lists of donors printed in An Appeal on behalf of The Calcutta School of Tropical Medicine and Hygiene and Carmichael Hospital for Tropical Diseases ${ }^{51}$ it is apparent that the Indian community gave about two and a half times more money than the European community (individuals and business considered together). ${ }^{52}$ The Indian donations, often in excess of Rs 1,000, came from the middle classes and elite Indian society in Bengal. Why was there such an interest among Indians in what was ostensibly an imperial project? On the one hand their desire to contribute to hospitals and medical schools may be seen as self-congratulatory, especially by those whose names appeared above the wards and beds. However, it can be argued that this represented an acknowledgement of the secular western value system of solving problems with science, and was thus a part of the cultural imperialism which long outlived direct political control. ${ }^{53}$ The politically moderate groups sought to secure a democratic, self-governing India though the reform of Indian society and life by accepting and adapting western models. Support for the CSTM from the Indian community was a part of this reform and remodelling.

These points are exemplified in the role of Sir Koilash Chandra Bose (1850-1927). ${ }^{54}$ Bose was a western-educated physician, a graduate of the Calcutta Medical College, who played a prominent role in Calcutta's municipal and medical politics. He was also an acknowledged social reformer who perceived health as social policy as well as medical care. He acted as a Municipal Commissioner for twenty-two years, and supported attempts to improve public health in Calcutta. He was an honorary magistrate and a member of the Calcutta corporation, a change from the usual "Hindu landowners and lawyers". ${ }^{55}$ As a founder member of the Calcutta Medical Club, he served as its president during the early years, a measure of the respect accorded to him by his Indian contemporaries. He published regularly in the Club's organ, the Calcutta Medical Journal. Rogers and Bose were close personal friends before work began on the School, and Bose had been actively involved in raising donations for the CSTM Endowment Fund from its inception. As at 21 December 1921, contributions received through him and his own gifts totalled Rs $80,628.56$ The large sum aside, Bose's fund raising is significant because the money came from groups not normally renowned for their charitable giving or a high degree of

\footnotetext{
${ }^{51}$ Rogers declined the offer of having the hospital named after him and instead chose to use the name of the Governor of Bengal.

52 CMAC, PP/ROG/C.18/231.

53 S I Habib, 'Promoting science and its world view in the mid-nineteenth century India', in Kumar, op. cit., note 7 above.
}

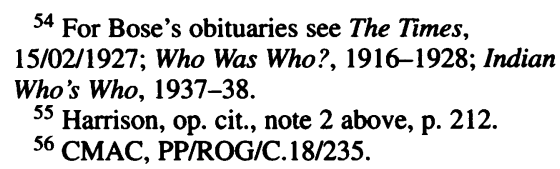

54 For Bose's obituaries see The Times, 15/02/1927; Who Was Who?, 1916-1928; Indian Who's Who, 1937-38.

55 Harrison, op. cit., note 2 above, p. 212.

56 CMAC, PP/ROG/C.18/235. 


\section{The Calcutta School of Tropical Medicine}

westernization. For instance the Marwari traders of northern Calcutta from whom Bose collected large donations, are also known for their participation in the all-India movements of the First World War period. ${ }^{57}$

Bose was not a member of the IMS. He represented the independent medical profession which Morley had tried to foster from 1905 onwards as part of the "Indianization" of the services and the executive and legislative councils. Bose's involvement was not connected with direct professional advancement, although he was knighted, and in 1923 appointed Honorary Physician to the Medical College Hospital. As will be discussed below, the employment of Indian IMS officers, let alone non-IMS Indian practitioners, in the CSTM was not a high priority for any of the government agencies. Bose's efforts on behalf of the school indicated a different long-term view of the school's role from that which Rogers as an IMS officer had planned. Instead of remaining the preserve of the white civil IMS, Bose perceived that the greatest benefit for Indians lay in the gradual "Indianization" of the school, staff and students, so that before the transfer of political power granted at independence, at the local level and in all spheres of activity, western imperial staff would be replaced with suitably trained people, thereby achieving Gopal K Gokhale's selective "assimilation of all that is best in the life and thought and character of the West". 58 Thus the CSTM as an imperial institution may not have appealed to the extreme nationalist movement, who wished for an immediate transfer to power, but was attractive to those members of elite Indian society who wished for change within the existing political framework.

\section{Staffing of the School}

Originally the GoI had agreed a salary increment for the three professors of pathology, biology, and medicine in the Medical College, who would teach the postgraduates in addition to their existing duties. The CSTM had undergone three metamorphoses since then, each time becoming a more substantial undertaking. The Gol's letter number 834 which referred to a "small scale undertaking" had, according to Rogers, also implied a fully-equipped institution "with a special staff of its own" for the future. ${ }^{59}$ In his view, the school had come of age, the foundation stone ceremony making this public. Rogers had learned unofficially from Lukis that an additional fifteen appointments to the Bacteriological Department had recently been sanctioned by the Secretary of State for India. He hoped to obtain men from this cadre. Not only were they suitably qualified, but also, if they drew their pay directly from the GoI, it would acknowledge the school's imperial nature. Prestige aside, it may have been his intention to avoid the increasing pressure from Britain to make provincial medical care open to private Indian practitioners, and to side-step the anti-IMS agitation from the nationalists. ${ }^{60}$

\footnotetext{
57 A L Basham, A cultural history of India, Oxford, Clarendon Press, 1975, p. 402.

58 Ibid, p. 392.

59 IOR, P/8442, Proc. No. 89.

${ }^{60}$ Medicine, like other British "goods", was a target of the Swadeshi Movement. Rogers gave
}

evidence before a Royal Commission into the Services in 1913, and the Hindoo Patriot, $17 / 01 / 1914$, attacked his view that "the steady decline in the private practice of the European members of the IMS has been due to the Swadeshi Movement". 


\section{Helen Power}

Rogers, in consultation with Harris, the IGCH, asked the GoI to provide six full time chairs: tropical medicine, bacteriology/pathology, protozoology, entomology/ helminthology, biochemistry/serology and pharmacology. He wanted the chair of tropical medicine, with control of the proposed hospital, for himself. Negotiations had started with the Rockefeller Foundation over their possible funding of the protozoology chair, although ultimately they withdrew their support because they felt they would not have enough control of the position. The chair in biochemistry and serology was earmarked for Lt-Col. William D Sutherland (1866-1920), whose initial investigations on the medicolegal aspects of bloodstains had brought him to Calcutta. The chair of pharmacology had special support from Colonel Harris, a former pharmacology professor, and personally interested in the Indian pharmacopoeia. The Indigenous Drugs Committee, set up in 1895 on an ad hoc basis, had various individuals working and reporting to the GoI, but the results became progressively less good. ${ }^{61}$ In exchange for the money they invested, the GoI were planning to use the CSTM to tidy up several loose ends.

However, progress on the staffing issue came to an abrupt halt. In May 1912, Major William Glen Liston had submitted a detailed proposal to the Government of Bombay outlining his scheme for a school of tropical medicine in conjunction with the Bombay Bacteriological Laboratory and the proposed King Edward Memorial Hospital. In many respects it resembled the CSTM, but Liston's intention was primarily the postgraduate education of Indians who had qualified at the Grant Medical College, preparing them for a Bachelor of Hygiene degree. The GoI declined the suggestion that "the Imperial Government should create an endowment fund towards the recurring cost of the new [Bombay] school", on the grounds that this was a local not a national matter. ${ }^{62}$ They suggested instead that Liston apply to Sir Dorab Tata to combine the vacant professorial chairs at the Indian Institute of Science with the proposed school in Bombay. Crucially, they redesignated the CSTM as a local project in line with the way they had viewed the Bombay proposal. Thus within a month of the foundation stone ceremony they declined to support the teaching staff as they had originally planned. In its turn the GoB now found itself unable to meet the demands for extra men and returned to the plan of additional allowances to existing Medical College staff. Rogers' personal aim had been the betterment of his research resources, and the creation of a set of full-time research posts for top IMS men. Rather than increased facilities, he was facing a deterioration in the existing situation. He called the GoB's bluff. On 17 March 1914, he wrote to Colonel Harris intimating that he would resign his post at the Medical College, which now included the additional duties at the new school. He explained he could not do justice to both positions and was prepared to move aside for someone who could, thereby saving the GoI any embarrassment.

This decision left Rogers out on a limb as far as the administration were concerned, the ICS officers considered that he was moving too fast and demanding too much. ${ }^{63}$ Colleagues at the Medical College rose to his defence, and informed the GoB that the additional workload would inevitably disadvantage either the undergraduates, or the postgraduates, or both. Help came from an unexpected quarter. An apparently misinformed editorial in the Englishman of 4 April 1914, entitled 'Tropical School of

${ }^{61}$ WBSA, Proc. No. B276, GoB Financial Dept, file $2 S-2$.
62 IOR, P/9209, Proc. No. 50.

${ }^{63}$ WBSA, Proc. No. B1264, Financial Dept. 


\section{The Calcutta School of Tropical Medicine}

Medicine/Dispute over the staffing/Sensational development/Possible resignation of Professor Rogers', claimed that he objected to the School being staffed with IMS men. ${ }^{64}$ Press coverage of the public furore was extremely convenient, such, it seemed, was his popularity. The GoB quickly arranged a meeting with Rogers where he presented a compromise of three professorial posts: tropical medicine, pathology/bacteriology (including helminthology), and protozoology/entomology. Colonel Harris insisted that the pharmacology chair be retained, and the GoB proposed that the school should be opened with these staff plus five demonstrators. Calvert, principal of the Medical College, intimated that the University of Calcutta would find it hard to grant a diploma, "unless the classes and teaching ... conducted by the whole-time professors ... approaches in some measure the accepted standard of tropical schools at home and abroad nor could I, as Dean of the Faculty of Medicine, conscientiously advise them otherwise" ${ }^{65}$ Rogers continued the pressure, writing to Stephenson, Secretary to the GoB:

from what $I$ know of the feeling in commercial circles, unless the whole-time staff of professors is appointed by Government, little or no help will be forthcoming for either endowment of research or the hospital. It may therefore be said that there is every possibility of a sum of about five lakhs being raised, three for research and two for the hospital if a proper staff is appointed by Government and failing the support of the GoI that sum will be lost. You will no doubt be able to make a strong point of this. ${ }^{66}$

By 26 April 1915 the GoB had persuaded the GoI of the need to fund the extra posts. ${ }^{67}$ The GoI also insisted on appointing Lt-Col. W D Sutherland, the Imperial Serologist, to the chair of biochemistry/serology, and guaranteed his salary from imperial revenues. In applying to the Secretary of State for sanction, the GoI agreed to pay as a gift the salary of two officers who would take on the posts of pathology/bacteriology and protozoology/entomology from the IRFA.

What of the hopes for Indianization? The men chosen for the professorial posts were all European IMS officers and those nominated for the research endowments (funded by the tea, jute and mining associations), although not all IMS men, were still Europeans. In 1914, Dr Nilratan Sarkar (1861-1943), a councillor and campaigner against discrimination between British and Indian doctors, had asked if the "Government [would] be pleased to state whether any Indians who have won distinction in clinical research work are to be appointed to any of the higher posts in the proposed school of tropical medicine?". ${ }^{68}$ The GoB avoided the question, replying that staffing proposals were still before the Secretary of State. In the debates which followed over the level of staffing and the source of funding the question of the race of the staff did not reappear in the Proceedings.

No provision was made by the Government or the CSTM Endowment Fund for Indians to develop their research work in the school. Assistant-surgeons were already employed in the pathological and physiological laboratories of the various government medical colleges and schools, but performed only a limited amount of their own research. Rogers considered that "very few Indian medical men [had] yet distinguished themselves", in this

${ }^{64}$ Rogers, op. cit., note 3 above, p. 165.

65 WBSA, Proc. No. B1264, Financial Dept. 66 Ibid.
${ }^{67}$ IOR, P/9953, Proc. No. 1.

68 WBSA, Proc. No. 34, Financial Dept, file no. $\mathrm{Q} / 13-4$. 
field and acknowledged that this was due to a "want of favourable conditions for work". 69 He was aware too that the nature of their duties prevented sustained investigation over long periods of time, and that the levels of pay were so poor that private practice was more appealing than unprofitable research. Yet he failed to voice the most obvious disincentive: that by dint of hard work the assistant surgeon ought to be able to progress in his career, but was thwarted because of the colour of his skin. Moreover, Rogers was not prepared to use the CSTM to create suitable conditions for this prejudice to be overcome and for Indian researchers to be able to advance. Among the Indian communities, there was direct support for Indian research staff, in addition to the general donations to the CSTM Endowment Fund. The "Mitra Memorial Medical Research Scholarship for Indians" and the "Darbhanga Medical Research Scholarship for Indians" were reserved specifically for Indian students. Their costs were met by Mrs A Mitra, widow of the late Dr Mitra of Kashmir, and the Maharajah Bahadur of Darbhanga. There was also the token gesture of the Minto Memorial Medal. This was endowed by Lady Minto, and would be awarded annually by a selection committee to an Indian candidate who had published medical research work of outstanding merit during the previous five years.

Active exclusion of Indians had not been a primary intention in establishing organized medical research in Calcutta, although the promotion of Indian research had not been a priority either. Since the idea for a school in Calcutta had been formulated, the CSTM had became a banner for the European members of the IMS, particularly the civil branch. Fears abounded that "Indianization" of the posts of civil surgeons would deter men with families from joining all the Indian services; those in the Mofussil (up country) particularly feared being without European medical care for themselves and their families. ${ }^{70}$ Failure to attract the right sort of white recruits for all the Indian services, the ICS, the police, the IMS, and the military, ultimately threatened the continued occupation of India by the British. The effects of the Morley-Minto reforms, World War I, and finally the Government of India Act of 1919, which transferred medical education, care and public health into the hands of an Indian Minister under the system of diarchy, made the control and staffing of CSTM an increasingly political issue. Indeed the repeated delays and changes in plan which had been used by Rogers to enhance the school had also postponed the decisions over staffing until a time when this had become a much more emotive issue. In Rogers' view Indianization was to increase, not decrease, the need for European staff, for Indians would need to be trained and there were as yet insufficient qualified Indian staff to achieve this. The European IMS would be required to build up a cadre of trained Indian staff capable of teaching to the same standard as the Europeans if the whole system of medical education were not to spiral downwards and decay. His attitudes were hardened after he became involved with the school by a greater awareness

\footnotetext{
${ }^{69}$ CMAC, PP/ROG/C.18/223.

${ }^{70}$ Letters from the European Defence Association and the Bengal and Burma Chambers of Commerce Committees expressed the "desirability of placing the civil surgeoncies throughout India gradually in the hands of fully-qualified European Officers." IOR, P/9457, Proc. No. 34. The emotive issue of contact between the races, even professional contact in a clinical consultation, was questioned. The British
}

\begin{abstract}
demanded that "the sacred right [that] every man and more especially every woman seeks to exercise, of being professionally attended by a qualified practitioner of his or her own race, custom, and ideas in life" be upheld by excluding Indian doctors from civil posts. Without these postings they were effectively bared from promotion to a chair or to the administration of health care.
\end{abstract}




\section{The Calcutta School of Tropical Medicine}

of the politics of medical provision, and by the effects of the Government of India Act of 1919. Rogers pressed for the CSTM as an "all-India" undertaking, as it had originally been designated, to be given special administrative status that removed it from provincial control, and (like other aspects of higher education) to be a "reserved subject not handed over to Indian administrators to be educated in administration". ${ }^{71}$ In his view it should not be treated as a part of the medical and public health infrastructure which passed to provincial Indian control in 1919, but, as a centre of higher medical education in India, it must be maintained as a reserved subject under central, and therefore European, control. The GoI did not accept Rogers' plea, as the staffing issue demonstrated, they had already abandoned the once imperial nature of the school. When the CSTM opened its doors to students in 1921, it looked towards the future of Indian health in Indian hands and not to its colonial past. A hygiene institute was added, and a course in tropical hygiene instigated. Rogers had organized a governing body for the CSTM Endowment Fund, based on the principles of the Rockefeller Institute and the IRFA. This allowed the appointed committee to take decisions on the management of the fund, as well as on the choice of research, without resort to the cumbrous procedures of the government secretariat. The members of the governing body reflecting those who had contributed to the CSTM, included Bose, its staff, and the top IMS administrators. At Rogers' behest, Major John W D Megaw (1874-1958), very much his protégé, was chosen as the first director.

The School's inauguration offered postgraduate education in tropical medicine within the Indian subcontinent for the first time. Officers of the IMS were eligible to study there for the diplomas in Tropical Medicine and Hygiene at a fraction of the cost of travelling to Europe. Local governments were also invited to share in the benefits, and practitioners from each province were chosen to receive higher postgraduate training at the school every year. This was intended to increase the numbers of teachers and public health workers, and thereby raise the standards of efficiency of Indian doctors. Such practitioners would be eligible for the research posts in government bacteriological laboratories. These had once been the retreat of the best IMS men, but with the general decline in white recruitment they could no longer be staffed with sufficient Europeans.

\section{Conclusion}

Various interests groups were involved in the CSTM. The GoB, the GoI, IMS officers, western-educated Indian practitioners, and interested Indian nationals, all contributed in diverse ways; each perceiving a different potential in a postgraduate centre for tropical medicine on the periphery of the empire. On several occasions the GoB and the GoI expressed the desire that the CSTM should function at the forefront of research and education in tropical medicine. Yet their provision of funds was usually halting and illustrates the low status accorded to medicine on the agenda of imperialism. The transfer of the school under the 1919 Government of India Act to the control of an elected provincial government reinforces the idea that this was not considered a key area of

\footnotetext{
71 Rogers' reply to Circular 32 of 6 April 1909, on the reduction of IMS officers in favour of locally recruited Indian practitioners, makes his position on
}

this issue of race quite clear, CMAC, PP/ROG/D.5/3-4. 


\section{Helen Power}

administration. The School building was combined with the much needed biological laboratory of the Medical College, and served to make Calcutta a centre for medical research, an important point following the transfer of the capital to New Delhi.

The GoI was able to combine several disjointed research efforts under one roof. The Imperial Serologist and the professor of pharmacology were now housed with proper facilities. Opening the school to official and non-official medical men was an attempt to quieten nationalist accusations against the IMS and to comply with Morley's desire to foster an independent medical profession which could assume the posts of the civil branch of the IMS. Much of the Gol's input was due to the energy and enthusiasm of the DGIMS, Sir Charles Pardey Lukis, without whose support it is unlikely the school would have evolved in the way it did.

For the officers of the IMS (especially the European ones), the CSTM offered better opportunities for research than previously found in the service. It was seen as a inducement to new home recruitment, although this failed to materialize. If the school had been run as Rogers hoped, it would have created a series of good professorial posts in the civil branch to replace the increasing number of posts for civil-surgeons offered to independent, indigenous medical practitioners.

For Indian medical graduates, whether or not in the IMS, the school offered a chance for professional advancement, which otherwise involved an expensive trip to Europe, beyond the reach of most, and against the tenets of the Hindu religion. The apparent success story of the school's early history and the training opportunities for Indian graduates repaid the interest of people like Koilash Chandra Bose. However, this occurred in the context of falling British recruitment for the IMS, more than through special initiatives from the school. Active discrimination against Indian doctors continued until the outbreak of World War II, the process of Indianization being slower in the IMS than in the other services.

Finally, for Rogers the School and attached hospital offered everything he had wanted and thought he deserved while in India. Although he was always full of praise for those Indians whom he knew personally and who worked with him, he was unable to extend this support for the benefit of Indian medical men in general in any really constructive manner. He could not break out of the paternalism which characterized the late Victorian era in which he had begun his imperial service with a high sense of Christian duty. However, despite the gradual transition from his ideals, the Calcutta school remained the most tangible legacy of his career. 